\title{
Çok Kriterli Karar Verme Yöntemleri AHP ve PROMETHEE ile Bursiyer Seçimi
}

\author{
Emre ASLAN ${ }^{1}$ ve Mehmet Erdoğan BAĞ $\breve{G}^{2}$
}

$\ddot{O} z$

Çok Kriterli Karar Verme (ÇKKV) yöntemleri birden fazla kriter ve birden fazla alternatif olan durumlarda alternatiflerin sınıflanması, sıralanması ve seçimi için kullanılan tekniklerdir. Bu çalışmada burs verilecek öğrencilerin daha kolay ve adil şekilde belirlenmesi problemine Analitik Hiyerarşi Prosesi (AHP) ve PROMETHEE yöntemlerinden yararlanan bir çözüm önerisi sunulmuştur. Belirlenen beş kriter olan gelir, anne babanın durumu, okuyan kardeş sayısı, ailenin oturduğu ev, sosyal güvenlik kriterlerinin ağırlıkları AHP ile iki karar vericinin yaptığı ikili karşılaştırmaların geometrik ortalaması alınıp sentezleme işlemi yapılarak tespit edilmiştir. Aday öğrencilerin sıralanması ise PROMETHEE yöntemi ile gerçekleştirilmiş ve burs verilecek öğrenciler belirlenmesi için bir öneri olarak sunulmuştur.

Anahtar Kelimeler: Çok Kriterli Karar Verme, AHP, PROMETHEE, burs

\section{Scholarship Selection with Multi-Criteria Decision Making Methods AHP and PROMETHEE}

\begin{abstract}
Multi-Criteria Decision Making (MCDM) methods are used for classification, ranking and selection of alternatives in cases where there are more than one criterion and more than one alternative. In this study Analytical Hierarchy Process (AHP) and Preference Ranking Organisation Method for Enrichment Evaluations (PROMETHEE) were suggested for determining the students to be awarded a scholarship among the applicants easily and fair. Weights of criteria (income, status of parents, number of siblings, family's home, social security) are determined with synthesis process of AHP by geometric means of pairwise comparisons of two decision makers. PROMETHEE was used for ranking the applicants and suggested as a method for determining the students to be awarded a scholarship.
\end{abstract}

Key Words: Multi-Criteria Decision Making, AHP, PROMETHEE, scholarship

Atıf İçin / Please Cite As:

Aslan, E ve Bağ, M. E. (2021). Çok kriterli karar verme yöntemleri AHP ve PROMETHEE ile bursiyer seçimi. Manas Sosyal Arastirmalar Dergisi, 10(4), 2301-2313.

Geliş Tarihi / Received Date: 07.06.2020

Kabul Tarihi / Accepted Date: 03.09.2021

\footnotetext{
${ }^{1}$ Dr. Öğr. Üyesi - Tokat Gaziosmanpaşa Üniversitesi İktisadi ve İdari Bilimler Fakültesi, emre.aslan@gop.edu.tr

ORCID: 0000-0002-1744-8077

2 Doktora Öğrencisi - Tokat Gaziosmanpaşa Üniversitesi Lisansüstü Eğitim Enstitüsü, mehmet.e.bag@gmail.com

(iD) ORCID: 0000-0002-6327-4450
} 


\section{Giriş}

Yükseköğretimde başarlı ve maddi durumu yeterli olmayan öğrenciler için gerek kendi üniversiteleri gerekse yerel ve ulusal kamu ve özel kurumlar tarafindan karşıllksız burslar verilebilmektedir. Bu tarz burslara ise başvuru sayısı çok olabilmekte, buna karşın sınırlı sayıda kişinin seçiminde objektif bir değerlendirme zor olabilmektedir. Çok sayıda burs başvurusu arasından çok sayıda kritere göre sıralama ve seçim yapma durumunda çok kriterli karar verme yöntemleri kullanılabilir.

Çok kriterli karar verme yöntemleri birden fazla kriter ve birden fazla alternatif olan durumlarda alternatiflerin sınıflanması, sıralanması ve seçimi için kullanılan yöntemlerdir. Bu yöntemlerin çok yaygin bir kullanım alanı vardır. Gerek bireyler gerekse kurumlar kısa, orta ve uzun vadede alternatifler arasından seçim yapma ihtiyacı hissederler, genellikle bu seçim esnasında dikkate alınacak birden fazla kriter vardır. Bireysel olarak herhangi bir ürünün (örneğin cep telefonu, otomobil, konut, ...) tercih edilmesi veya kurumsal olarak herhangi bir ürün veya hizmetin (tedarikçi seçimi, makine satın alınması, işe eleman alımı, ...) seçimi örnek olarak gösterilebilir.

$\mathrm{Bu}$ çalışmada bir üniversitede burs verilecek öğrencilerin belirlenmesi problemine AHP ve PROMETHEE yöntemleri kullanılarak bir çözüm sunulmuştur. Lisans düzeyinde eğitim veren bir bölümdeki öğrencilere verilecek bir burs için bursiyerlerin seçimi konusunda karar verici iki akademisyenin daha adil bir şekilde bu seçimi yapma isteği çalş̧manın çıkış noktası olmuştur. Bu amaçla belirlenen kriterlerin ağırlıklandırılmasında karar vericilerin yaptıkları ikili karşılaştırmalar dikkate alınarak AHP yöntemi kullanılmıştır. Bursiyer seçiminde ise gerçek veriler etik kaygılarla bu çalısmada kullanılmamış, bunun yerine gerçek verilerin temel bazı istatistikleri kullanılarak türetilen veriler kullanılmış, PROMETHEE yöntemi ile seçim yapılmıştır. Çalışmanın bundan sonraki bölümlerinde sırasıyla AHP ve PROMETHEE yöntemleri kısaca açılanmış, konu ile ilgili literatür özetlenmiş, uygulama problemleri çözülerek çalışma sonuçlandırılmıştır.

\section{Analitik Hiyerarşi Prosesi (AHP)}

Analitik Hiyerarşi Prosesi 1970’li yılların ortasında Thomas L. Saaty tarafindan geliştirilen ölçme ve karar verme için kullanılan bir matematiksel teoridir (Saaty ve Niemira, 2006, s. 1). AHP literatürde yaygin olarak çalışılmıştır ve son 20 yılda çok kriterli karar verme ile ilgili pek çok çalışmada kullanılmıştır (Ho, 2008, s. 211). Aytaç ve Bayram (2001) üniversite öğrencilerinin iş ve eş seçimindeki etkin kriterleri, Oğuzlar (2007), otomobillerle ilgili müşteri şikâyetlerinin analizinde, Eleren (2007), beyaz eşya sektöründe büyük, küçük ve diğer elektrikli ev aletleri olmak üzere üç alt grubun tümünde ürün üreten veya pazarlayan markalardan en çok tanınanları çalışmaya alarak tüketici tercih kriterlerine göre sıralamada, Atan vd. (2008), insan kaynakları seçiminde AHP tekniğini kullanmışlardır. Güngör vd. (2010), Türkiye'de il olmas1 uygun olan ilçelerin öncelik sıralamasını, İbicioğlu ve Ünal (2014), insan kaynakları yöneticisi seçimi için bir model geliştirmişler ve modelin oluşturulmasını, Akça vd. (2015), kişi takip cihazı seçiminde AHP tekniğini kullanmışlardır.

AHP yönteminin uygulama adımlarını şu şekilde özetlemek mümkündür:

1. Adım: Hiyerarşik Yapının Oluşturulması: Karar amacı ile tepeden başlayarak karar hiyerarşisi oluşturulur. Orta seviyede kriterler ve en düşük seviyede ise alternatifler bulunur (Saaty, 2008, s. 85).

2. Adım: Kriterlerin ve Alternatiflerin Öncelik Değerlerinin Belirlenmesi: Bu çalışmada AHP sadece kriterlerin öncelik değerlerinin hesaplanmasında kullanılacaktır. Alternatiflerin nihai öncelik değerleri AHP'den elde edilen kriterlerin öncelik değerleri (ağırlıklar) dikkate alınarak PROMETHEE yöntemi ile hesaplanacaktır. Öncelik değerleri ikili karşılaştırmalar ile belirlenir. Kriter sayısı $n$ ise $\left(\begin{array}{l}n \\ 2\end{array}\right)$ yani $n$ 'in ikili kombinasyonu kadar ikili karşılaşıırma yapmak gerekir. İkili karşılaştırmalarda bir taraftaki kriterin diğerine göre ne kadar önemli veya baskın olduğunu göstermek için Tablo 1'deki gibi 1'den 9'a kadar bir sayı ölçeğine ihtiyaç duyulur (Saaty, 2008, s. 85). Bu ölçekle yapılan ikili karşılaştırmalar sonucunda ikili karşılaştırmalar matrisi elde edilir. Satırdaki elemanın sütundakine göre ne kadar önemli olduğunu $\left(a_{i j}\right)$ gösteren bu matrisin köşegene göre simetrisinde ise aşağıdaki gibi bu değerin tam tersi $\left(a_{j i}=1 / a_{i j}\right)$ yer alır (Saaty, 2016, s. 369).

$$
A=\left(\begin{array}{cccc}
1 & a_{12} & \ldots & a_{1 n} \\
1 / a_{12} & 1 & \ldots & a_{2 n} \\
\vdots & \vdots & 1 & \vdots \\
1 / a_{1 n} & 1 / a_{2 n} & \ldots & 1
\end{array}\right)
$$


Tablo 1. İkili Karşılaşttrmalarda Mutlak Saynlardan Oluşan Temel Ölçek

\begin{tabular}{clclcl}
\hline ÖIçek & \multicolumn{1}{c}{ Tanım } & ÖIçek & Tanım & ÖIçek & \multicolumn{1}{c}{ Tanım } \\
\hline 1 & Eşit önemde & 4 & Orta üstü & 7 & Çok kuvvetli önemde \\
2 & Zayıf veya hafif & 5 & Kuvvetli önemde & 8 & Çok çok kuvvetli \\
3 & Orta önemde & 6 & Kuvvetli üstü & 9 & Aşsı̈ önemde \\
\hline
\end{tabular}

Yukarıdakilerin karşıtı $i$ elemanı $j$ elemanı ile karşılaştırıldığında kuvvetli derecede önemli ise 5 değerini alır ve $j$ elemanı $i$ elemanı ile karşılaștırıldı̆̆ında $1 / 5$ değerini alır.

Kaynak: (Saaty, 2008, s. 86).

İkili karşılaştırmalar matrisi normalize edilir. Bunun için matristeki her bir değer sütun toplam değerine bölünür.

$$
b_{i j}=\frac{a_{i j}}{\sum_{i=1}^{n} a_{i j}} \quad \forall i, j
$$

Normalize edilmiş matrisin satır ortalamaları alındığında her satır için elde edilen değer o satırdaki elemanın öncelik değerini verir.

$$
w_{i}=\frac{\sum_{j=1}^{n} b_{i j}}{n} \quad \forall i
$$

3. Adım: Tutarlılık Oranlarının Hesaplanması: İkili karşılaştırmaların tutarlı yapıldığını tespit edebilmek için tutarlılık oranının hesaplanması gerekir. Bunun için öncelikle ikili karşılaştırmalar matrisi ile öncelik vektörü çarpıllır $c_{i j}$ elemanları olan $C$ matrisi elde edilir.

$$
c_{i j}=w_{i} \cdot b_{j i}
$$

$C$ matrisinin satır toplamları alınıp öncelik vektöründeki ilgili satırın önceliğine bölünür.

$$
d_{i}=\frac{\sum_{j=1}^{n} c_{i j}}{w_{i}} \quad \forall i
$$

$d_{i}$ değerlerinin ortalaması alınarak $\lambda_{\max }$ değeri hesaplanır.

$$
\lambda_{\max }=\frac{\sum_{i=1}^{n} d_{i}}{n}
$$

Tutarlılık İndeksi (TI) aşağıdaki şekilde hesaplanır.

$$
T I=\frac{\lambda_{\max }-n}{n-1}
$$

Son olarak Tutarlılık İndeksi (TI) Rassal İndekse (RI) bölünerek Tutarllık Oranı (TO) hesaplanır. Rassal İndeks rassal olarak oluşturulan ikili karşılaştırma matrislerinin ortalama tutarllık indeksidir ve karşılaştırılan elemanların sayısına bağlı olarak Tablo 2'deki değerleri alır. Eğer hesaplanan tutarlılık oranı 0,10 değerinin altında ise karşılaştırmalann yeterli tutarlılığa sahip olduğu kabul edilir.

$$
T R=\frac{T I}{R I}
$$

Tablo 2. Rassal Indeks Degererleri

\begin{tabular}{ccccccccc}
\hline $\boldsymbol{n}$ & 3 & 4 & 5 & 6 & 7 & 8 & 9 & 10 \\
\hline $\boldsymbol{R} \boldsymbol{I}$ & 0,58 & 0,90 & 1,12 & 1,24 & 1,32 & 1,41 & 1,45 & 1,49 \\
\hline
\end{tabular}

4. Nihai Öncelik Değerlerinin Belirlenmesi: AHP'de kriterlerin kendi içinde önceliklendirilmesi ve her kriter açısından alternatiflerin önceliklendirilmesi yapıldıktan sonra her alternatifin her kriter açısından öncelik değeri ile o kriterin öncelik değeri çarpılarak toplanır ve her alternatifin nihai öncelik değeri elde edilir. Elde edilen nihai öncelik değerleri azalan şekilde sıralandığında tercih sıralaması da yapılmış olur. $\mathrm{Bu}$ çalışmada AHP sadece kriterlerin ağılıklandırılması için kullanıldığından bu aşama uygulamada kullanılmayacaktır. 


\section{PROMETHEE}

PROMETHEE (Preference Ranking Organisation Method for Enrichment Evaluations) yöntemi, Brans tarafından 1982'de literatüre kazandırılmış, Brans ve Vincke (1985) tarafından geliştirilmiştir. PROMETHEE yönteminin temel özellikleri basitlik, açıklık ve dengeli oluşudur. Yöntem sıralama oluştururken tercih fonksiyonlarını kullanır. Karar vericinin kararını kolay bir şekilde oluşturması için bütün parametrelerin açık bir şekilde belirlenmiş olması gerekmektedir. PROMETHEE yöntemi ile sonlu sayıda alternatifler üzerinde hem kısmi siralama (PROMETHEE I) hem de tam siralama (PROMETHEE II) yapmak mümkündür (Brans vd., 1986, s. 228). Yöntemle ilgili Behzadian vd.' nin (2010) detaylı literatür taramasına göre çevre yönetimi, hidroloji ve su yönetimi, işletme ve finansal yönetim, kimya, lojistik ve taşımacılık, imalat ve montaj, enerji yönetimi, sosyal ve diğer farklı konularda uygulama alanı bulmaktadır. Yöntemin aşamaları aşağıdaki gibi özetlenebilir.

1. Adım: Alternatifler, kriterler ve kriter ağırlıklarının belirlenmesi: Bu aşamada karar problemi için alternatifler, bu alternatiflerin seçim ve/veya sıralamasında dikkate alınacak kriterler ve bu kriterlerin ağırlıkları belirlenir.

2. Adım: Her Kriter için tercih fonksiyonlarının belirlenmesi: Tercih fonksiyonlanı her kriter için ayrı olarak tanımlanıp $a$ ile $b$ karşılaştırıldığında karar vericinin tercihini belirten 0 ile 1 arasında değer alan bir fonksiyondur. Değer sıfira yaklaştıkça karar vericinin iki eleman arasında kayıtsız olduğunu, değer bire yaklaştıkça karar vericinin elemanlardan birisini diğerine daha fazla tercih ettiğini göstermektedir (Brans ve Vincke, 1985, s. 649). Tablo 3'te gösterilen altı tip tercih fonksiyonu vardır (Brans ve De Smet, 2016, s. 194-195).

3. Adım: Her kriter açısından tercih fonksiyonuna göre alternatif çiftleri için tercih değerlerinin belirlenmesi: $\mathrm{Bu}$ aşamada her kriter için alternatif sayısı kadar satır ve sütuna sahip matrisler oluşturulur. Her matriste satırdaki eleman sütundakine göre üstünlüğe sahip ise tercih fonksiyonu değeri yazılır, aksi takdirde sıfır değeri girilir.

Tablo 3. Tercih Fonksiyonlar $P(d)$

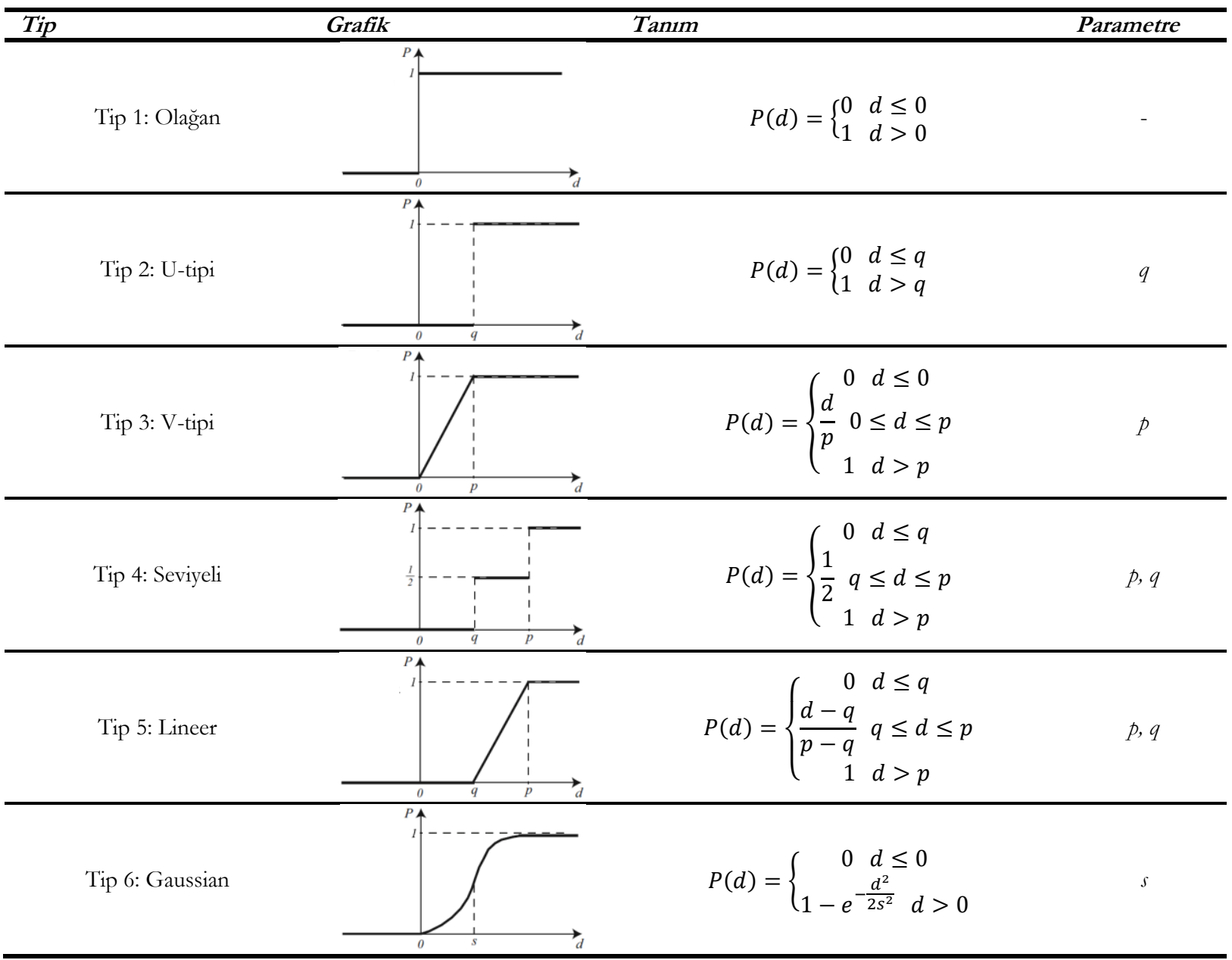

Kaynak: Brans ve De Smet, 2016, s. 195 
4. Adım: Tercih İndekslerinin Belirlenmesi: Her bir kriter açısından alternatif çiftleri için oluşturulmuş tercih fonksiyonu matrisleri her bir kriterin ağırlık değeri ile çarpılarak toplanır ve ağırlıklandırılmış tercih indeksi matrisi elde edilir.

5. Adım: Alternatifler için Pozitif ve Negatif Üstünlüklerin Belirlenmesi: Ağıllıklandırılmış tercih indeksi matrisinin satır ve sütun toplamları hesaplanır. Satır toplamları, satırdaki alternatifin diğer tüm alternatiflere karşı üstünlügünü (pozitif üstünlük $\phi^{+}$), sütun toplamları ise diğer tüm alternatiflerin sütundaki alternatife karşı üstünlügünü (negatif üstünlük $\phi^{-}$) belirtir.

6. Adım: PROMETHEE I ile kısmi önceliklerin belirlenmesi: Kısmi önceliklere göre aşağıdaki koşullardan birisi sağlanıyorsa $a$ alternatifi $b$ 'ye tercih edilir.

$$
\begin{aligned}
& \phi^{+}(a)>\phi^{+}(b) \text { ve } \phi^{-}(a)<\phi^{-}(b) \\
& \phi^{+}(a)=\phi^{+}(b) \text { ve } \phi^{-}(a)<\phi^{-}(b) \\
& \phi^{+}(a)>\phi^{+}(b) \text { ve } \phi^{-}(a)=\phi^{-}(b)
\end{aligned}
$$

Aşağıdaki koşul sağlanıyorsa $a$ ve $b$ farksızdır.

$$
\phi^{+}(a)=\phi^{+}(b) \text { ve } \phi^{-}(a)=\phi^{-(b)}
$$

Aşağıdaki koşullardan birisi sağlanıyorsa $a$ ve $b$ karşılaştırılamaz.

$$
\begin{aligned}
& \phi^{+}(a)>\phi^{+}(b) \text { ve } \phi^{-}(a)>\phi^{-}(b) \\
& \phi^{+}(a)<\phi^{+}(b) \text { ve } \phi^{-}(a)<\phi^{-}(b)
\end{aligned}
$$

7. Adım: PROMETHEE II ile tam önceliklerin belirlenmesi: Bir alternatifin tam önceliği aşağıdaki gibi pozitif üstünlük ve negatif üstünlük arasındaki fark ile belirlenir. Alternatifler tam öncelik değerlerine göre azalan şekilde sıralandıklarında tercih edilebilirlik sıralaması da belirlenmiş olur.

$$
\phi(a)=\phi^{+}(a)-\phi^{-}(b)
$$

\begin{tabular}{|c|c|c|}
\hline Yazar (Tarih) & Yöntem & Kriterler \\
\hline Yeh (2003) & $\begin{array}{l}\text { basit ağırlıklandırma, } \\
\text { ağırlıklı ürün, TOPSIS }\end{array}$ & $\begin{array}{l}\text { toplum hizmeti, spor/hobiler, iş tecrübesi, enerji, iletişim becerisi, } \\
\text { akademik alana karşı tavır, olgunluk, liderlik }\end{array}$ \\
\hline Erdem Hacıköylü (2006) & AHP & $\begin{array}{l}\text { ailenin gelir durumu, öğrencinin başarı durumu, öğrencinin barındığı yer, } \\
\text { ailenin diğer özellikleri (çocuk sayısı, anne babanın varlığı kardeşin eğitim } \\
\text { durumu) }\end{array}$ \\
\hline $\begin{array}{l}\text { Sulaiman ve Mohamad } \\
(2006)\end{array}$ & $\begin{array}{l}\text { bulanık mantık karar } \\
\text { modeli }\end{array}$ & akademik nitelik, çalışma alanının ilgili olması, mülakat performansı \\
\hline $\begin{array}{l}\text { Demirci ve Küçük } \\
\text { (2007) }\end{array}$ & AHP & $\begin{array}{l}\text { yaşanacak yer, lise mezuniyet derecesi, sosyal güvenlik durumu, anne } \\
\text { babanın hayatta olup olmaması, anne babanın birlikte olup olmaması, } \\
\text { okuyan toplam kardeş sayısı, ailenin toplam geliri, aile reisinin bakmakla } \\
\text { yükümlü olduğu toplam kişi sayısı, ailenin oturduğu evin kira olup } \\
\text { olmaması, danışman hocanın görüşü }\end{array}$ \\
\hline Küçük vd. (2008) & $\begin{array}{l}\text { genetik algoritma ve } \\
\text { AHP ile karşllaştırma }\end{array}$ & $\begin{array}{l}\text { yaşanacak yer, lise mezuniyet derecesi, sosyal güvenlik durumu, anne } \\
\text { babanın hayatta olup olmaması, anne babanın birlikte olup olmaması, } \\
\text { okuyan toplam kardeş sayısı, ailenin toplam geliri, aile reisinin bakmakla } \\
\text { yükümlü olduğu toplam kişi sayısı, ailenin oturduğu evin kira olup } \\
\text { olmaması, danışman hocanın görüșü }\end{array}$ \\
\hline Uyun ve Riadi (2011) & $\begin{array}{l}\text { çok değişkenli karar } \\
\text { verme, TOPSIS }\end{array}$ & $\begin{array}{l}\text { kümülatif not ortalaması, ailenin geliri/ekonomik durumu, ailedeki birey } \\
\text { sayısı, dini/ahlaki yönü, muhakeme ve idealizm yönü, liderlik ve sadakat } \\
\text { yönü, ilgi alanı ve yetenek yönü, profesyonel faaliyetler, toplum hizmeti }\end{array}$ \\
\hline Abalı vd. (2012) & AHP, TOPSIS & $\begin{array}{l}\text { ailenin bakmakla yükümlü olduğu çocuk sayısı, ailenin toplam aylık geliri, } \\
\text { anne baba durumu, ailenin sahip olduğu toplam mülk sayısı, öğrencinin } \\
\text { çalışma durumu }\end{array}$ \\
\hline
\end{tabular}

\section{Literatür}

Burs için çok kriterli karar verme yöntemleri ile öğrenci sıralaması ve seçimi üzerine literatürde rastlanılan çalışmalar, kullanılan yöntemler ve kriterler Tablo 4'te özetlenmiştir. Çalışmaların geneli incelendiğinde AHP yönteminin özellikle kriterlerin ağıllıklandırılmasında sıklıkla kullanıldı̆̆1 görülmektedir.

Tablo 4. Burs İ̧̧in Ögrenci Seçiminde Çok Kriterli Karar Verme Yöntemleri ile İlgili Literatür 
ASLAN ve BAĞ

Çok Kriterli Karar Verme Yöntemleri AHP ve PROMETHEE ile Bursiyer Seçimi

\begin{tabular}{|c|c|c|}
\hline Guo vd. (2013) & AHP & $\begin{array}{l}\text { çalışma puanı (zorunlu ve seçmeli dersler), normal puan (ahlaki puan, } \\
\text { okuma yazma, spor ve rekabet puanı) ek puan (ödül puanı ve kadro } \\
\text { puanı) }\end{array}$ \\
\hline Saragih vd. (2013) & $\begin{array}{l}\text { bulanık çok kriterli karar } \\
\text { verme, TOPSIS }\end{array}$ & $\begin{array}{l}\text { not ortalaması, tutum, disiplin, ilaç kullanımı, kampüs organizasyonlarına } \\
\text { katılım }\end{array}$ \\
\hline Silva vd. (2014) & PROMETHEE & yaş/sınıf bozulması, okul performansı, sıklık düzeni, okula yakınlık, gelir \\
\hline $\begin{array}{l}\text { Saptarini ve Prihatini } \\
(2015)\end{array}$ & AHP, TOPSIS & ebeveynlerin geliri, ailedeki fert sayısı, akademik ve akademi dışı başarı \\
\hline $\begin{array}{l}\text { Indriantoro ve Utami } \\
(2016)\end{array}$ & PROMETHEE & not ortalaması, ebeveyn geliri, ebeveyne bağımlı kişiler, sömestr, başarı \\
\hline $\begin{array}{l}\text { Purba ve Sembiring } \\
\text { (2016) }\end{array}$ & PROMETHEE & $\begin{array}{l}\text { not ortalaması, devam, disiplin, durum, psikolojik testler, mülakat, } \\
\text { arkadaş ve hoca görüşleri }\end{array}$ \\
\hline Putra vd. (2016) & AHP, SVM, TOPSIS & $\begin{array}{l}\text { Gelir, bağımlı kişi sayısı, ebeveyn mesleği, elektrik maliyeti, evin durumu, } \\
\text { arsa ve inşaat vergisi, toplam araç sayısı }\end{array}$ \\
\hline Irvanizam (2017) & $\begin{array}{l}\text { AHP, basit ağırlıklı } \\
\text { ortalama }\end{array}$ & not ortalaması, alınan kredi puanı sayısı, kardeş sayısı, ebeveyn geliri \\
\hline Pençe vd. (2017) & AHP, TOPSIS & $\begin{array}{l}\text { öğrencinin yaşı, cinsiyeti, sınıfı, başarısız ders sayısı, ÖSYM sıralaması, } \\
\text { anne ve baba durumu, ailesinin bakmakla yükümlü olduğu çocuk sayısı, } \\
\text { ailesinin yıllık geliri, ailenin mülk durumudur }\end{array}$ \\
\hline Sriwahyuni vd. (2017) & AHP & $\begin{array}{l}\text { gelişim raporu puanı, akademik başarı, ders dışı başarı, ebeveyn geliri, } \\
\text { ebeveynlere bağımlı birey sayısı }\end{array}$ \\
\hline Taufik vd. (2017) & PROMETHEE & $\begin{array}{l}\text { baba mesleği, anne mesleği, ebeveyn geliri, aileye bağımlı yaşlı insan sayısı, } \\
\text { konut sahipliği, faal olma }\end{array}$ \\
\hline Widiantoro (2017) & AHP & $\begin{array}{l}\text { öğrencinin bölümü/programı, ana tavsiye, not ortalaması, burs program } \\
\text { elemesini geçmiş olma, başarı disiplini ve arzusu }\end{array}$ \\
\hline Aini vd. (2018) & PROMETHEE & $\begin{array}{l}\text { akademik rapor endeksi, en endeksi (sahiplik durumu, ev kalitesi, inşaat } \\
\text { alanı, elektrik enerjisi, elektrik ödemesi), bağımlı aile üyesi sayısı, ebeveyn } \\
\text { geliri (babanın geliri, annenin geliri) }\end{array}$ \\
\hline Andriani vd. (2018) & $\begin{array}{l}\text { k-ortalama kümeleme, } \\
\text { AHP }\end{array}$ & $\begin{array}{l}\text { başarı indeksi, kredi sayısı, sömestr, ders dışı başarı, ebeveyn geliri, } \\
\text { ebeveynlere bağımlılık }\end{array}$ \\
\hline Mahmud vd. (2018) & bulanik AHP & akademik performans, ebeveyn geliri, ders dışı aktiviteler \\
\hline $\begin{array}{l}\text { Napitupulu ve Surbakti } \\
(2018)\end{array}$ & AHP & ekonomik durum, akademik başarı, örgütsel canlılık, ders dışı başar1 \\
\hline Puspitasari vd. (2018) & AHP & ebeveyn geliri, daha az harç ödeme, bağımlı kişi sayısı \\
\hline Satriani vd. (2018) & AHP, PROMETHEE & ebeveyn geliri, ebeveyn gideri, not ortalaması, ebeveyne bağıml kişiler \\
\hline Hasan vd. (2019) & AHP, TOPSIS & $\begin{array}{l}\text { not ortalaması, başvuru dosyasının eksiksiz olması, ebeveynlerin geliri, } \\
\text { ebeveynlere bağımlı kişi sayısı (çocuklar), çalışma durumu }\end{array}$ \\
\hline Yang ve He (2019) & $\begin{array}{l}\text { AHP, resim bulanık } \\
\text { küme, TOPSIS }\end{array}$ & $\begin{array}{l}\text { ideoloji ve ahlak (disiplin, öğretmen-öğrenci ilişkisi, sınıf arkadaşlarıyla } \\
\text { ilişki), akademik başarı (İngilizce ve bilgisayar puanları, alan ortalaması, } \\
\text { genel ortalama) fiziksel ve zihinsel kalite (fiziksel uygunluk, spor yeteneği, } \\
\text { zihinsel sağlık), inovasyon yeteneği (yayımlanan çalışma sayısı, yarışma } \\
\text { ödülü, bilimsel araştırma projesi), uygulama faaliyetleri (faaliyetlere } \\
\text { katılım, örgütsel yönetim yeteneği) }\end{array}$ \\
\hline
\end{tabular}

Yapılan çalışmaların geneline bakıldığında gerek kriterler gerek yöntem(ler) açısından birbirlerinden farklı oldukları görülmektedir. Her bir çalışmanın farklı bir kurum, farklı bir birim ve farklı ihtiyaçlar için yapıldığı göz önüne alındığında kriterlerin farklılaşması doğaldır. Literatürde PROMETHEE kullanan 6 çalışmaya rastlanmış, bunlardan sadece birisinde bu yöntem AHP ile kullanılmaktadır. Bu çalışma da gerçek bir problemi esas alıp kendi kriterlerini belirlemiş olması ve nispeten az kullanılan bir yöntemi kullanması nedeniyle diğer çalışmalardan belli ölçüde farklılaşmaktadır.

\section{Yöntem}

Bu çalışmada, bir üniversitenin lisans düzeyindeki bir bölümünde burs başvurusu yapan öğrenciler arasında seçim yapma işini daha kolay ve adil yapmaya yönelik beş kriter belirlenmiştir. Bu kriterlerin belirlenmesinde literatürde sık karşılaşılan kriterler dikkate alınmış, bununla birlikte bölümün bağlı olduğu fakültedeki standart burs başvuru formunda istenen bilgiler de belirleyici olmuştur. Ayrıca özellikle maddi durumu yeterli olmayan öğrenciler için verilen bir burs olmasından dolayı ÖSYM puanı, not ortalaması gibi akademik başarı kriterleri dikkate alınmamıştır. Buna göre belirlenen kriterler şunlardır:

- Gelir (öğrencinin ailesinin aylık gelir düzeyi) (GLR)

- Anne babanin durumu (ABD)

- Okuyan kardeş sayısı (OKS)

- Ailenin oturduğu ev (kira / ev sahibi) (AOE)

- Sosyal güvenlik (SG) 
Kriterlerin ağırlıklandırılmasında AHP yönteminin yapıtaşı olan ikili karşılaştırmalar kullanılmıştır. Karar verici iki akademisyenin yaptıkları ikili karşılaştırmaların geometrik ortalamaları alınıp sentezlenerek kriterlerin ağırlıkları tespit edilmiştir. Her iki karar vericinin ikili karşılaştırmalarının (Tablo 5) tutarlılık oranları hesaplanmış ve yeterli tutarlılıkta bulunmuştur $(T R 1=0,081 ; \operatorname{TR} 2=0,096)$.

Tablo 5. Karar Vericilerin İkili Karşılaştırmalar Matrisi

\begin{tabular}{|c|c|c|c|c|c|c|c|c|c|c|c|}
\hline \multicolumn{6}{|c|}{ Karar Verici 1} & \multicolumn{6}{|c|}{ Karat Verici 2} \\
\hline & $G L R$ & $A B D$ & $O K S$ & $A O E$ & $S G$ & & $G L R$ & $A B D$ & $O K S$ & $A O E$ & $S G$ \\
\hline GLR & 1 & 7 & 6 & 8 & 5 & GLR & 1 & 7 & 5 & 9 & 7 \\
\hline$A B D$ & 0,143 & 1 & 0,25 & 3 & 0,333 & $A B D$ & 0,143 & 1 & 0,200 & 2 & 0,500 \\
\hline OKS & 0,167 & 4 & 1 & 3 & 0,500 & OKS & 0,200 & 5 & 1 & 6 & 5 \\
\hline$A O E$ & 0,125 & 0,333 & 0,333 & 1 & 0,200 & $A O E$ & 0,111 & 0,500 & 0,167 & 1 & 0,200 \\
\hline$S G$ & 0,200 & 3 & 2 & 5 & 1 & $S G$ & 0,143 & 2 & 0,200 & 5 & 1 \\
\hline
\end{tabular}

İki karar vericinin ikili karşılaştırmalarının geometrik ortalamaları alınarak grup kararı olarak nitelenebilecek ikili karşılaştırmalar matrisi oluşturulmuştur (Tablo 6). Bu ikili karşılaştırmalar matrisinin tutarlılık oranı da yeterli olarak hesaplanmıştır $(T R=0,061)$.

Tablo 6. Iki Karar Vericinin İkili Karşılasstırmalar Matrisinin Geometrik Ortalaması

\begin{tabular}{|c|c|c|c|c|c|}
\hline & $G L R$ & $A B D$ & $O K S$ & $A O E$ & $S G$ \\
\hline$G L R$ & 1 & 7 & 5,477 & 8,485 & 5,916 \\
\hline$A B D$ & 0,143 & 1 & 0,224 & 2,449 & 0,408 \\
\hline OKS & 0,183 & 4,472 & 1 & 4,243 & 1,581 \\
\hline$A O E$ & 0,118 & 0,408 & 0,236 & 1 & 0,200 \\
\hline$S G$ & 0,169 & 2,449 & 0,632 & 5 & 1 \\
\hline
\end{tabular}

Elde edilen ikili karşılaştırmalar matrisinde AHP yönteminin sentezleme işlemi uygulanmış ve buna göre kriterlerin ağırlıkları Tablo 7'deki gibi hesaplanmıstır. Buna göre en önemli kriter \%57 ağırlıkla "Gelir" kriteridir. En önemsiz kriter ise \%4 ağırlık ile “Ailenin Oturduğu Ev” kriteridir.

Tablo 7. Kriterlerin Ağrrlıklar

\begin{tabular}{ccccc}
\hline $\boldsymbol{G L} \boldsymbol{R}$ & $\boldsymbol{A B D}$ & $\boldsymbol{O K S}$ & $\boldsymbol{A O E}$ & $\boldsymbol{S} \boldsymbol{G}$ \\
\hline 0,570 & 0,069 & 0,182 & 0,040 & 0,139 \\
\hline
\end{tabular}

Bursiyer seçiminde gerçek veriler etik kaygılar nedeniyle kullanılmamış, bunun yerine gerçek verilerin temel bazı istatistikleri (Gelir için en düşük 500, en yüksek 6000, ortalama 2250; Anne Baba Durumu için $\% 1$ ikisi de hayatta değil, \%9 birisi hayatta, \%90 her ikisi de hayatta; Okuyan Kardeş Sayısı en düşük 1, en yüksek 8; Ailenin Oturduğu Ev \%80 ev sahibi, \%20 kira (en düşük kira 300, en yüksek kira 1100); Sosyal Güvenlik \%40 yeşil kart veya yok, \%60 SGK, Emekli sandığ1) dikkate alınarak 50 öğrencilik bir veri seti türetilmiştir. Tablo 8'de kriterler ile ilgili türetilen veriler gösterilmiştir. 
Tablo 8. Burs Başvurusu Yapan Ögrencilerin Bilgileri

\begin{tabular}{|c|c|c|c|c|c|c|c|c|c|c|c|}
\hline $\operatorname{Aday} \mathbf{N o}$ & $G L R$ & $A B D$ & $O K S$ & $A O E$ & $S G$ & $\operatorname{Aday} \mathbf{N o}$ & $G L R$ & $A B D$ & $O K S$ & $A O E$ & $S G$ \\
\hline 1 & 2000 & 2 & 4 & 0 & 1 & 26 & 3500 & 1 & 2 & 0 & 1 \\
\hline 2 & 2000 & 2 & 1 & 0 & 1 & 27 & 3000 & 2 & 3 & 0 & 1 \\
\hline 3 & 2000 & 2 & 1 & 0 & 1 & 28 & 3000 & 2 & 3 & 0 & 1 \\
\hline 4 & 2500 & 2 & 1 & 0 & 1 & 29 & 2500 & 2 & 1 & 0 & 1 \\
\hline 5 & 1900 & 2 & 1 & 800 & 0 & 30 & 1000 & 2 & 3 & 0 & 1 \\
\hline 6 & 2000 & 2 & 2 & 450 & 0 & 31 & 2000 & 1 & 2 & 800 & 1 \\
\hline 7 & 2000 & 2 & 4 & 0 & 0 & 32 & 6000 & 2 & 3 & 700 & 1 \\
\hline 8 & 1000 & 2 & 4 & 0 & 0 & 33 & 2000 & 2 & 2 & 0 & 0 \\
\hline 9 & 2000 & 2 & 3 & 300 & 0 & 34 & 2500 & 2 & 1 & 0 & 1 \\
\hline 10 & 1500 & 2 & 8 & 0 & 0 & 35 & 2600 & 2 & 2 & 0 & 1 \\
\hline 11 & 4000 & 2 & 4 & 0 & 0 & 36 & 1000 & 2 & 2 & 0 & 0 \\
\hline 12 & 3500 & 1 & 2 & 0 & 1 & 37 & 1750 & 2 & 2 & 0 & 0 \\
\hline 13 & 3500 & 2 & 1 & 0 & 0 & 38 & 900 & 2 & 3 & 0 & 1 \\
\hline 14 & 3200 & 2 & 6 & 0 & 1 & 39 & 1500 & 2 & 4 & 600 & 1 \\
\hline 15 & 3000 & 2 & 3 & 0 & 0 & 40 & 1500 & 1 & 2 & 400 & 1 \\
\hline 16 & 2500 & 2 & 1 & 1100 & 1 & 41 & 1100 & 2 & 1 & 0 & 0 \\
\hline 17 & 1800 & 2 & 2 & 0 & 1 & 42 & 1750 & 2 & 2 & 0 & 1 \\
\hline 18 & 1600 & 2 & 1 & 0 & 1 & 43 & 2000 & 2 & 1 & 600 & 1 \\
\hline 19 & 1200 & 2 & 1 & 0 & 0 & 44 & 2000 & 2 & 2 & 0 & 1 \\
\hline 20 & 1200 & 2 & 2 & 0 & 0 & 45 & 2000 & 2 & 1 & 0 & 1 \\
\hline 21 & 2000 & 2 & 2 & 0 & 1 & 46 & 2250 & 2 & 1 & 0 & 1 \\
\hline 22 & 500 & 0 & 1 & 0 & 1 & 47 & 2500 & 2 & 3 & 500 & 1 \\
\hline 23 & 3500 & 2 & 1 & 0 & 1 & 48 & 2500 & 2 & 1 & 0 & 1 \\
\hline 24 & 1500 & 1 & 1 & 0 & 1 & 49 & 3000 & 2 & 1 & 0 & 0 \\
\hline 25 & 4000 & 2 & 3 & 0 & 0 & 50 & 3000 & 2 & 1 & 0 & 0 \\
\hline
\end{tabular}

Bursiyer seçiminde PROMETHEE yöntemi kullanılmıștır. Bu yöntemde her bir kriter açısından alternatiflerin birbirlerine üstünlüğu tercih fonksiyonları ile 0 ile 1 arasinda belirlenmektedir. Tablo 9'da bu çalş̧mada kullanılan kriterler, her bir kriter açısından amaç (maksimizasyon veya minimizasyon) ve hangi tercih fonksiyonunun kullanıldığ1 belirtilmiştir.

Tablo 9. Kriterler ve Tercih Fonksiyonlar

\begin{tabular}{c|cccc}
\hline Kriter & Ölçüm & Amaç & Tercih Fonksiyonu & Parametreler \\
\hline $\boldsymbol{G L} \boldsymbol{R}$ & $\ldots$ TL & $\min$ & Tip 5 & $q=100, p=400$ \\
$\boldsymbol{A} \boldsymbol{B D}$ & Her ikisi de hayatta 2; Birisi hayatta 1; İkisi de hayatta değil 0 & $\min$ & Tip 4 & $q=0,99, p=1,98$ \\
$\boldsymbol{O} \boldsymbol{K} \boldsymbol{S}$ & $\ldots$ & $\max$ & Tip 4 & $q=1, p=2$ \\
$\boldsymbol{A} \boldsymbol{O E}$ & $\ldots$ TL kira bedeli; ev sahibi ise 0 & $\max$ & Tip 4 & $q=250, p=500$ \\
$\boldsymbol{S} \boldsymbol{G}$ & SGK, Emekli sandığ 1; Yeşil kart, Yok 0 & $\min$ & Tip 1 & - \\
\hline
\end{tabular}

GLR kriteri için Tip 5 tercih fonksiyonu uygun olarak belirlenmiştir. Bu tercih fonksiyonuna göre belirlenen bir alt limitten (q) daha az fark olması durumunda alternatiflerin birbirlerine karşı üstünlükleri olmayacak (0), bir üst limitten (p) fazla fark olması durumunda biri diğerine mutlak üstün olacak (1), eğer alt ve üst limit arasında fark var ise 0 ile 1 arasında lineer artan bir üstünlük olacaktır. Burada alt limit olarak 100 TL, üst limit olarak ise 400 TL belirlenmiştir.

$\mathrm{ABD}$, OKS ve AOE kriterleri için Tip 4 tercih fonksiyonu uygun olarak belirlenmiştir. Bu tercih fonksiyonuna göre belirlenen bir alt limitten (q) daha az fark olması durumunda alternatiflerin birbirlerine karşı üstünlükleri olmayacak, bir üst limitten (p) fazla fark olması durumunda biri diğerine mutlak üstün olacak, eğer alt ve üst limit arasında fark var ise kısmi bir üstünlük $(0,5)$ olacaktır. ABD kriteri için örneğin anne babasının ikisi de hayatta olmayan bir öğrenci her ikisi de hayatta olan birisine göre mutlak üstün, birisi hayatta olan birisine göre kısmi üstün olacaktır. OKS kriteri için örneğin okuyan kardeş sayısı 4 olan bir öğrenci 1 olan birisine göre mutlak üstün, 2 olan birisine göre kısmi üstün, 3 olan birisinden farksız olacaktır. AOE kriterine göre örneğin ailesi 900 TL kira ödeyen bir öğrenci, 300 TL kira ödeyen birisine göre mutlak üstün, 500 TL kira ödeyen birisine göre kısmi üstün, 700 TL kira ödeyen birisinden farksız olacaktır. 
SG kriteri Tip 1 tercih fonksiyonu uygun olarak belirlenmiştir. Bu tercih fonksiyonuna göre iki kişi arasında olumsuz fark olması durumunda biri diğerine mutlak üstün (1), olumlu fark olması veya farkın 0 olması durumunda farksız (0) olacaktır. Örneğin ailesi yeşil kart sahibi olan veya sosyal güvenliği olmayan bir öğrenci, ailesi emekli sandığı veya SGK'ya bağlı bir öğrenciye göre mutlak üstün olacaktır.

Tablo 9'da geçen tercih fonksiyonlarına göre adayların her bir kriter açısından birbirlerine göre tercih edilebilirlikleri 0 ile 1 arasında değer alacak şekilde tespit edilmiş, bu değerler kriterlerin daha önce belirlenen ağırlıkları ile çarpılıp toplanmak suretiyle tercih indeksi matrisi Tablo 10'daki gibi elde edilmiştir.

Tablo 10. Ağrrlklandorlmıs Tercib İndeksi Matrisi

\begin{tabular}{|c|c|c|c|c|c|}
\hline & 1 & 2 & 3 & 4 & 5 \\
\hline 1 & & 0,18 & 0,18 & 0,75 & 0,18 \\
\hline 2 & 0,00 & & 0,00 & 0,57 & 0,00 \\
\hline 3 & 0,00 & 0,00 & & 0,57 & 0,00 \\
\hline 4 & 0,00 & 0,00 & 0,00 & & 0,00 \\
\hline 5 & 0,18 & 0,18 & 0,18 & 0,75 & \\
\hline 6 & 0,16 & 0,16 & 0,16 & 0,73 & 0,00 \\
\hline 7 & 0,14 & 0,32 & 0,32 & 0,89 & 0,18 \\
\hline 8 & 0,71 & 0,89 & 0,89 & 0,89 & 0,75 \\
\hline 9 & 0,16 & 0,25 & 0,25 & 0,82 & 0,09 \\
\hline 10 & 0,89 & 0,89 & 0,89 & 0,89 & 0,61 \\
\hline 11 & 0,14 & 0,32 & 0,32 & 0,32 & 0,18 \\
\hline 12 & 0,03 & 0,03 & 0,03 & 0,03 & 0,03 \\
\hline 13 & 0,14 & 0,14 & 0,14 & 0,14 & 0,00 \\
\hline 14 & 0,09 & 0,18 & 0,18 & 0,18 & 0,18 \\
\hline 15 & 0,14 & 0,23 & 0,23 & 0,23 & 0,09 \\
\hline 16 & 0,04 & 0,04 & 0,04 & 0,04 & 0,02 \\
\hline 17 & 0,14 & 0,14 & 0,14 & 0,57 & 0,00 \\
\hline 18 & 0,43 & 0,43 & 0,43 & 0,57 & 0,29 \\
\hline 19 & 0,71 & 0,71 & 0,71 & 0,71 & 0,57 \\
\hline 20 & 0,71 & 0,71 & 0,71 & 0,71 & 0,57 \\
\hline 21 & 0,00 & 0,00 & 0,00 & 0,57 & 0,00 \\
\hline 22 & 0,64 & 0,64 & 0,64 & 0,64 & 0,64 \\
\hline 23 & 0,00 & 0,00 & 0,00 & 0,00 & 0,00 \\
\hline 24 & 0,60 & 0,60 & 0,60 & 0,60 & 0,46 \\
\hline 25 & 0,14 & 0,23 & 0,23 & 0,23 & 0,09 \\
\hline 26 & 0,03 & 0,03 & 0,03 & 0,03 & 0,03 \\
\hline 27 & 0,00 & 0,09 & 0,09 & 0,09 & 0,09 \\
\hline 28 & 0,00 & 0,09 & 0,09 & 0,09 & 0,09 \\
\hline 29 & 0,00 & 0,00 & 0,00 & 0,00 & 0,00 \\
\hline 30 & 0,57 & 0,66 & 0,66 & 0,66 & 0,66 \\
\hline 31 & 0,07 & 0,07 & 0,07 & 0,64 & 0,03 \\
\hline 32 & 0,04 & 0,13 & 0,13 & 0,13 & 0,09 \\
\hline 33 & 0,14 & 0,14 & 0,14 & 0,71 & 0,00 \\
\hline 34 & 0,00 & 0,00 & 0,00 & 0,00 & 0,00 \\
\hline 35 & 0,00 & 0,00 & 0,00 & 0,00 & 0,00 \\
\hline 36 & 0,71 & 0,71 & 0,71 & 0,71 & 0,57 \\
\hline 37 & 0,35 & 0,35 & 0,35 & 0,71 & 0,07 \\
\hline 38 & 0,57 & 0,66 & 0,66 & 0,66 & 0,66 \\
\hline 39 & 0,61 & 0,79 & 0,79 & 0,79 & 0,61 \\
\hline 40 & 0,62 & 0,62 & 0,62 & 0,62 & 0,46 \\
\hline 41 & 0,71 & 0,71 & 0,71 & 0,71 & 0,57 \\
\hline 42 & 0,21 & 0,21 & 0,21 & 0,57 & 0,07 \\
\hline 43 & 0,04 & 0,04 & 0,04 & 0,61 & 0,00 \\
\hline 44 & 0,00 & 0,00 & 0,00 & 0,57 & 0,00 \\
\hline 45 & 0,00 & 0,00 & 0,00 & 0,57 & 0,00 \\
\hline 46 & 0,00 & 0,00 & 0,00 & 0,21 & 0,00 \\
\hline 47 & 0,02 & 0,11 & 0,11 & 0,11 & 0,09 \\
\hline 48 & 0,00 & 0,00 & 0,00 & 0,00 & 0,00 \\
\hline 49 & 0,14 & 0,14 & 0,14 & 0,14 & 0,00 \\
\hline 50 & 0,14 & 0,14 & 0,14 & 0,14 & 0,00 \\
\hline & 26 & 27 & 28 & 29 & 30 \\
\hline 1 & 0,66 & 0,57 & 0,57 & 0,75 & 0,00 \\
\hline 2 & 0,57 & 0,57 & 0,57 & 0,57 & 0,00 \\
\hline 3 & 0,57 & 0,57 & 0,57 & 0,5 & 0,00 \\
\hline 4 & 0,57 & 0,57 & 0,57 & 0,0 & 0,00 \\
\hline 5 & 0,75 & 0,75 & 0,75 & 0,75 & 0,18 \\
\hline 6 & 0,73 & 0,73 & 0,73 & 0,73 & 0,16 \\
\hline 7 & 0,80 & 0,71 & & 0,8 & \\
\hline 8 & 0,80 & 0,71 & & 0,8 & \\
\hline 9 & 0,73 & 0,73 & 0,73 & 0,82 & 0,16 \\
\hline 10 & 0,89 & 0,89 & 0,89 & 0,89 & 0,32 \\
\hline 11 & 0,23 & 0,1 & 0, & 0,3 & 0,1 \\
\hline 12 & 0,00 & 0,03 & 0,03 & 0,03 & 0,03 \\
\hline 13 & 0,14 & 0,14 & 0,14 & 0,14 & 0,14 \\
\hline 14 & 0,47 & & & 0,1 & \\
\hline $\begin{array}{l}14 \\
15\end{array}$ & 0,71 & 0,1 & 0, & 0,2 & \\
\hline 16 & 0,61 & 0,61 & 0,61 & 0,04 & 0,04 \\
\hline 17 & 0,57 & 0,57 & 0,57 & 0,57 & 0,00 \\
\hline 18 & 0,57 & 0,5 & & 0,5 & \\
\hline $\begin{array}{l}10 \\
19\end{array}$ & 0,71 & 0,7 & 0, & 0,7 & 0, \\
\hline 20 & 0,71 & 0,71 & 0,71 & 0,71 & 0,1 \\
\hline 21 & 0,57 & 0,57 & 0,57 & 0,57 & 0,00 \\
\hline 22 & & & & & \\
\hline 23 & 0,00 & 0,0 & 0,0 & 0,0 & 0,0 \\
\hline 24 & 0,57 & 0,60 & 0,60 & 0,60 & 0,03 \\
\hline 25 & 0,14 & 0,14 & 0,14 & 0,2 & 0,14 \\
\hline 26 & & 0,03 & 0,03 & 0,0 & \\
\hline 27 & 0,57 & & 0,00 & 0,09 & 0,0 \\
\hline 28 & 0,57 & 0,00 & & 0,09 & 0,00 \\
\hline 29 & 0,57 & 0,57 & 0,57 & & 0,00 \\
\hline 30 & 0,57 & 0,57 & 0,57 & 0,66 & \\
\hline 31 & 0,61 & 0,6 & 0,64 & 0,64 & 0,07 \\
\hline 32 & 0,0 & 0,0 & & 0, & \\
\hline 33 & 0,71 & 0,7 & 0, & 0,7 & \\
\hline 34 & 0,57 & 0,5 & 0,57 & 0,0 & 0,0 \\
\hline 35 & 0,57 & 0,4 & 0,4 & 0,0 & 0,0 \\
\hline 36 & 0, & 0 & & & \\
\hline 37 & 0,71 & 0,71 & 0,71 & 0,71 & 0,14 \\
\hline 38 & 0,57 & 0,57 & 0,57 & 0,66 & $\begin{array}{l}0,17 \\
0,00\end{array}$ \\
\hline 39 & 0,7 & 0, & 0,6 & 0,7 & \\
\hline 40 & 0,59 & 0,62 & 0, & 0,6 & 0, \\
\hline 41 & 0,71 & 0,71 & 0,71 & 0,71 & 0,14 \\
\hline
\end{tabular}




\begin{tabular}{|c|c|c|c|c|c|c|c|c|c|c|c|c|c|c|c|c|c|c|c|c|c|c|c|c|c|}
\hline 42 & 0,57 & 0,57 & 0,57 & 0,57 & 0,00 & 0,21 & 0,57 & 0,21 & 0,57 & 0,57 & 0,00 & 0,00 & 0,00 & 0,00 & 0,00 & 0,00 & & 0,21 & 0,21 & 0,21 & 0,57 & 0,57 & 0,57 & 0,57 & 0,57 \\
\hline 43 & 0,61 & 0,61 & 0,61 & 0,61 & 0,04 & 0,00 & 0,57 & 0,04 & 0,61 & 0,61 & 0,04 & 0,04 & 0,04 & 0,00 & 0,00 & 0,04 & 0,04 & & 0,04 & 0,04 & 0,25 & 0,57 & 0,61 & 0,61 & 0,61 \\
\hline 44 & 0,57 & 0,57 & 0,57 & 0,57 & 0,00 & 0,00 & 0,57 & 0,00 & 0,57 & 0,57 & 0,00 & 0,00 & 0,00 & 0,00 & 0,00 & 0,00 & 0,00 & 0,00 & & 0,00 & 0,21 & 0,57 & 0,57 & 0,57 & 0,57 \\
\hline 45 & 0,57 & 0,57 & 0,57 & 0,57 & 0,00 & 0,00 & 0,57 & 0,00 & 0,57 & 0,57 & 0,00 & 0,00 & 0,00 & 0,00 & 0,00 & 0,00 & 0,00 & 0,00 & 0,00 & & 0,21 & 0,57 & 0,57 & 0,57 & 0,57 \\
\hline 46 & 0,57 & 0,57 & 0,57 & 0,21 & 0,00 & 0,00 & 0,57 & 0,00 & 0,21 & 0,36 & 0,00 & 0,00 & 0,00 & 0,00 & 0,00 & 0,00 & 0,00 & 0,00 & 0,00 & 0,00 & & 0,21 & 0,21 & 0,57 & 0,57 \\
\hline 47 & 0,59 & 0,59 & 0,59 & 0,11 & 0,02 & 0,00 & 0,57 & 0,02 & 0,11 & 0,02 & 0,02 & 0,02 & 0,02 & 0,00 & 0,00 & 0,11 & 0,02 & 0,09 & 0,02 & 0,11 & 0,11 & & 0,11 & 0,68 & 0,68 \\
\hline 48 & 0,57 & 0,57 & 0,57 & 0,00 & 0,00 & 0,00 & 0,57 & 0,00 & 0,00 & 0,00 & 0,00 & 0,00 & 0,00 & 0,00 & 0,00 & 0,00 & 0,00 & 0,00 & 0,00 & 0,00 & 0,00 & 0,00 & & 0,57 & 0,57 \\
\hline 49 & 0,71 & 0,14 & 0,14 & 0,14 & 0,14 & 0,14 & 0,71 & 0,00 & 0,14 & 0,14 & 0,00 & 0,00 & 0,14 & 0,14 & 0,14 & 0,00 & 0,14 & 0,14 & 0,14 & 0,14 & 0,14 & 0,14 & 0,14 & & 0,00 \\
\hline 50 & 0,71 & 0,14 & 0,14 & 0,14 & 0,14 & 0,14 & 0,71 & 0,00 & 0,14 & 0,14 & 0,00 & 0,00 & 0,14 & 0,14 & 0,14 & 0,00 & 0,14 & 0,14 & 0,14 & 0,14 & 0,14 & 0,14 & 0,14 & 0,00 & \\
\hline
\end{tabular}

Tablo 10'da satır toplamları o adayın diğer tüm adaylara ne derece tercih edildiğinin bir göstergesi (pozitif üstünlük: $\phi^{+}$) olurken sütun toplamaları diğer tüm adayların o adaya ne derece tercih edildiğinin bir göstergesi (negatif üstünlük: $\phi$ ) olmaktadır. PROMETHEE II' ile tam öncelik değerlerinin $(\phi)$ belirlenmesi için her bir adayın pozitif üstünlük değerinden negatif üstünlük değerini çıkarmak gerekmektedir. Pozitif, negatif üstünlükler, tam öncelik değerleri Tablo 11'de verilmiştir.

Tablo 11. Pozitif ve Negatif Üstünlükler, Tam Öncelik Değerleri

\begin{tabular}{|c|c|c|c|c|c|c|c|c|c|c|c|c|c|c|c|c|c|}
\hline Aday & 1 & 2 & 3 & 4 & 5 & 6 & 7 & 8 & 9 & 10 & 11 & 12 & 13 & 14 & 15 & 16 & 17 \\
\hline$\phi^{+}$ & 17,3 & 12,2 & 12,2 & 8 & $\overline{18,6}$ & 17,6 & 21,9 & 34,5 & 19,5 & 34,1 & 10,3 & 3,3 & 6,3 & 11,4 & 11 & 9,9 & 14,2 \\
\hline$\phi^{-}$ & 11,2 & 13 & 13 & 21,9 & 9,1 & 9 & 8,7 & 1,4 & 8,6 & 4,4 & 28,2 & 28 & 27 & 25 & 21,9 & 21,6 & 9,7 \\
\hline$\phi$ & 6,1 & $-0,8$ & $-0,8$ & $-13,9$ & 9,6 & 8,6 & 13,2 & 33,1 & 10,9 & 29,7 & $-17,9$ & $-24,7$ & $-20,7$ & $-13,6$ & $-10,9$ & $-11,7$ & 4,5 \\
\hline Aday & 18 & 19 & 20 & 21 & 22 & 23 & 24 & 25 & 26 & 27 & 28 & 29 & 30 & 31 & 32 & 33 & 34 \\
\hline$\phi^{+}$ & 18,2 & 27,8 & 27,8 & 12,2 & 31,6 & 1,7 & 22,1 & 7,1 & 3,3 & 6,4 & 6,4 & 8 & 26,7 & 15,5 & 3,6 & 16,8 & 8 \\
\hline$\phi^{-}$ & 9,4 & 3,9 & 2,7 & 11,7 & 4,9 & 29,5 & 8,8 & 28,3 & 28 & 24,4 & 24,4 & 21,9 & 4 & 11,2 & 31,6 & 9,2 & 21,9 \\
\hline$\phi$ & 8,8 & 23,9 & 25,2 & 0,5 & 26,7 & $-27,8$ & 13,3 & $-21,2$ & $-24,7$ & -18 & -18 & $-13,9$ & 22,7 & 4,2 & -28 & 7,6 & $-13,9$ \\
\hline$\overline{\text { Aday }}$ & 35 & 36 & 37 & 38 & 39 & 40 & 41 & 42 & 43 & 44 & 45 & 46 & 47 & 48 & 49 & 50 & \\
\hline$\phi^{+}$ & 7,3 & 29,4 & 19,8 & 27,1 & 27,3 & 22,9 & 28,5 & 15,2 & 13,8 & 12,2 & 12,2 & 9,6 & 10,7 & 8 & 9 & 9 & \\
\hline$\phi^{-}$ & 20,8 & 2 & 6,9 & 3,9 & 6,9 & 7,3 & 3,4 & 9,4 & 12,7 & 11,7 & 13 & 17,1 & 19,9 & 21,9 & 23,6 & 23,6 & \\
\hline$\phi$ & $-13,5$ & 27,4 & 12,9 & 23,3 & 20,4 & 15,6 & 25,2 & 5,8 & 1,1 & 0,5 & $-0,8$ & $-7,5$ & $-9,2$ & $-13,9$ & $-14,6$ & $-14,6$ & \\
\hline
\end{tabular}

Tam öncelik değerleri azalan şekilde sıralanarak burs verilecek ilk 10 kişi Tablo 12 'deki gibi belirlenmiştir. Tam öncelik değerlerine göre burs için seçilen 10 aday $8,10,36,22,41,20,19,38,30,39$ olarak belirlenmiştir.

Tablo 12. Tam Öncelik Değerlerine Göre Azalan Siralama

\begin{tabular}{|c|c|c|c|c|c|c|c|c|c|c|c|c|c|c|c|c|c|}
\hline Tercih & 1 & 2 & $\begin{array}{r}3 \\
36\end{array}$ & 4 & $\begin{array}{r}5 \\
41\end{array}$ & 6 & $\begin{array}{r}7 \\
10\end{array}$ & $\begin{array}{r}8 \\
38\end{array}$ & 9 & 10 & 11 & 12 & 13 & 14 & 15 & 16 & $\begin{array}{l}17 \\
18\end{array}$ \\
\hline $\begin{array}{l}\text { Aday } \\
\phi\end{array}$ & $\begin{array}{r}8 \\
33,1\end{array}$ & $\begin{array}{r}10 \\
29,7\end{array}$ & $\begin{array}{r}36 \\
27,4\end{array}$ & $\begin{array}{r}22 \\
26,7\end{array}$ & $\begin{array}{r}41 \\
25,2\end{array}$ & $\begin{array}{r}20 \\
25,2\end{array}$ & $\begin{array}{r}19 \\
23,9\end{array}$ & $\begin{array}{r}38 \\
23,3\end{array}$ & $\begin{array}{r}30 \\
22,7\end{array}$ & $\begin{array}{r}39 \\
20,4\end{array}$ & $\begin{array}{r}40 \\
15,6\end{array}$ & $\begin{array}{r}24 \\
13,3\end{array}$ & $\begin{array}{r}7 \\
13,2\end{array}$ & $\begin{array}{r}37 \\
12,9\end{array}$ & $\begin{array}{r}9 \\
10,9\end{array}$ & $\begin{array}{r}5 \\
9,6\end{array}$ & $\begin{array}{r}18 \\
8,8\end{array}$ \\
\hline Tercih & 18 & 19 & 20 & 21 & 22 & 23 & 24 & 25 & 26 & 27 & 28 & 29 & 30 & 31 & 32 & 33 & 34 \\
\hline Aday & 6 & 33 & 1 & 42 & 17 & 31 & 43 & 21 & 44 & 2 & 3 & 45 & 46 & 47 & 15 & 16 & 35 \\
\hline$\phi$ & 8,6 & 7,6 & 6,1 & 5,8 & 4,5 & 4,2 & 1,1 & 0,5 & 0,5 & $-0,8$ & $-0,8$ & $-0,8$ & $-7,5$ & $-9,2$ & $-10,9$ & $-11,7$ & $-13,5$ \\
\hline Tercih & 35 & 36 & 37 & 38 & 39 & 40 & 41 & 42 & 43 & 44 & 45 & 46 & 47 & 48 & 49 & 50 & \\
\hline Aday & 14 & 4 & 29 & 34 & 48 & 49 & 50 & 11 & 27 & 28 & 13 & 25 & 12 & 26 & 23 & 32 & \\
\hline$\phi$ & $-13,6$ & $-13,9$ & $-13,9$ & $-13,9$ & $-13,9$ & $-14,6$ & $-14,6$ & $-17,9$ & -18 & -18 & $-20,7$ & $-21,2$ & $-24,7$ & $-24,7$ & $-27,8$ & -28 & \\
\hline
\end{tabular}

Bursiyer olarak seçilen adayların bilgileri Tablo 13'te verilmiștir. Bursiyerlerin bilgiler kriterlerin önem sırasına göre genel bilgiler ile karşılaştırıldığında: GLR (ağırlık: 0,570) ortalaması bursiyerler için 1090 iken, genel ortalama 2255, seçilmeyen adayların ortalaması 2546; OKS (ağırlık: 0,182) ortalaması bursiyerler için 3 , genel ortalama 2,18, seçilmeyen adayların ortalaması 2; SG (ağırlık: 0,139) sahibi olma yüzdesi bursiyerlerde $\% 40$, genelde $\% 64$, seçilmeyen adaylarda $\% 70$ olduğu hesaplanmıştır. Bu üç kriterin toplam ağırlığ1 0,891'dir. Geriye kalan iki kritere (ABD ve AOE; toplam ağıllk: 0,109) bakmadan dahi yöntemin doğru şekilde seçim yaptığı sonucuna varılabilir.

Tablo 13. Bursiyer Olarak Sę̧ilen Aday Bilgilerinin Karşılaştırması

\begin{tabular}{c|ccccc}
\hline Aday $\boldsymbol{N o}$ & $\boldsymbol{G L R}$ & $\boldsymbol{A B D}$ & $\boldsymbol{O K S}$ & $\boldsymbol{A O E}$ & $\boldsymbol{S} \boldsymbol{G}$ \\
\hline 8 & 1000 & 2 & 4 & 0 & 0 \\
10 & 1500 & 2 & 8 & 0 & 0 \\
36 & 1000 & 2 & 2 & 0 & 0 \\
22 & 500 & 0 & 1 & 0 & 1 \\
41 & 1100 & 2 & 1 & 0 & 0 \\
20 & 1200 & 2 & 2 & 0 & 0 \\
19 & 1200 & 2 & 1 & 0 & 0 \\
38 & 900 & 2 & 3 & 0 & 1 \\
30 & 1000 & 2 & 3 & 600 & 1 \\
39 & 1500 & 2 & 4 & & 1 \\
\hline
\end{tabular}




\section{Tartışma, Sonuç ve Öneriler}

Çok kriterli karar verme yöntemleri birden fazla kriter ve birden fazla alternatif olan durumlarda alternatiflerin sınıflanması, sıralanması ve seçimi için kullanılan yöntemlerdir. Bu çalışmada başvuran adaylar arasından bursiyerlerin daha kolay ve adil bir şekilde belirlenebilmesi için AHP ve PROMETHEE yöntemlerinden yararlanan bir öneride bulunulmuştur. AHP ile kriterlerin ağırlıkları karar verici iki kişinin yaptığı ikili karşılaştırmaların geometrik ortalaması alınıp sentezleme işlemi yapılarak tespit edilmiştir. Aday öğrencilerin sıralanması ve seçimi ise PROMETHEE yöntemi ile gerçekleştirilmiştir. Konu ile ilgili literatüre bakıldığında AHP yönteminin sıklıkla kullanıldı̆̆ı görülmektedir. PROMETHEE yöntemi ise farklı tercih fonksiyonu seçenekleri ile karar vericilerin farklı tipte veriler içeren kriterlere uygun olanı seçme imkanı sunmaktadır.

Bu çalışma mevcut bir bursiyer seçimi problemi esas alınarak gerçek veriler kullanılmadan türetilen veriler ile gerçekleştirilmiştir. İlerleyen dönemlerde gerçek problem üzerinde uygulanarak daha kolay ve adil bir seçim yapma imkanı sağlayacaktır. Gerekli durumlarda kriterlerin ağırlıklarını belirlemede temsiliyeti artırmak için daha çok karar vericinin görüşü alınabilir. Ayrıca daha sonraki çalışmalarda kriterler arası etkileşim dikkate alınabilir. Örneğin anne babanın durumu geliri etkileyebilmekte, gelir ile sosyal güvenlik arasında karşılıklı ilişsi olabilmektedir. Bu durum da dikkate alınarak gelecekteki çalısmalarda kriterlerin ağırlıklarını belirlemede AHP yerine Analitik A ̆g Süreci (ANP) tercih edilebilir.

\section{Etik Beyan}

"AHP ve PROMETHEE ile Burs Verilecek Ögrrencilerin Belirlenmesi" başlıklı çalışmanın yazım sürecinde bilimsel, etik ve alıntı kurallarına uyulmuş; toplanan veriler üzerinde herhangi bir tahrifat yapılmamış ve bu çalısma herhangi başka bir akademik yayın ortamına değerlendirme için gönderilmemiştir. Bu araştırmada hazır veri seti kullanıldığı için etik kurul kararı zorunluluğu taşımamaktadır.

\section{Kaynakça}

Abalı, Y. A., Kutlu, B. S. ve Eren, T. (2012). Çok ölçütlü karar verme yöntemleri ile bursiyer seçimi: Bir eğitim kurumunda uygulama. Atatïrk Üniversitesi İktisadi ve İdari Bilimler Dergisi, 26(3-4), 259-272.

Aini, Q., Hidayah, N. A. ve Istiqomah, A. N. (2018, August). Scholarship decision support system using preference ranking organization method for enrichment evaluation. In 2018 6th International Conference on Cyber and IT Service Management (CITSM) (pp. 1-5). IEEE.

Akça, B. A., Doğan, A. ve Özcan, U. (2015). Analitik hiyerarşi süreci kullanılarak kişi takip cihazı seçimi. Bilişim Teknolojileri Dergisi, 8(1), 20-35.

Andriani, R., Amanullah, R. F. ve Ninosari, D. (2018, December). Optimization of clustering algorithm on decision support system of scholarship recipients using analytical hierarchy process method. In Journal of Physics: Conference Series, 1140(1), p. 012028. IOP Publishing.

Atan, M., Atan, S. ve Altın, K. (2008). İnsan Kaynakları seçiminde analitik hiyerarşi süreci kullanımı ve bir yazılım önerisi. Gazi Üniversitesi I.I.I.B.F. Dergisi,10(3), 143-162.

Aytaç, S. ve Bayram, N. (2001). Üniversite gençliğinin iş ve eş seçimindeki etkin kriterlerinin analitik hiyerarşi süreci (AHP) ile analizi. $\dot{I}_{s}$ Gü̆, Endüstri İliskileri ve Insan Kaynaklar Dergisi, 3(1).

Behzadian, M., Kazemzadeh, R. B., Albadvi, A. ve Aghdasi, M. (2010). PROMETHEE: A comprehensive literature review on methodologies and applications. European journal of Operational research, 200(1), 198-215.

Brans, J. P. ve De Smet, Y. (2016). PROMETHEE methods. In Multiple criteria decision analysis (pp. 187-219). Springer, New York, NY.

Brans, J. P. ve Vincke, P. (1985). Note-A preference ranking organisation method: (The PROMETHEE Method for Multiple Criteria Decision-Making). Management science, 31(6), 647-656.

Brans, J., Vincke, P. ve Mareschal, B. (1986). How to select and how to rank projects: The PROMETHEE method. European Journal of Operational Research, 24, 228-238.

Demirci, E. ve B. Küçük. (2007). Bursiyerlerin analitik hiyerarşi prosesi (AHP) yardımı ile seçimi. yöneylem araştırması. Endüstri Mühendislï̆i 27. Ulusal Kongresi. 2-4 Temmuz 2007, İzmir.

Eleren, A. (2007). Markaların tüketici tercih kriterlerine göre analitik hiyerarşi süreci yöntemi ile değerlendirilmesi: Beyaz eşya sektöründe bir uygulama. Celal Bayar Üniversitesi Yönetim ve Ekonomi Dergisi, 4(2), 47-64.

Erdem Hacıköylü, B. (2006). Analitik bijerarşi karar verme süreci ile Anadolu Üniversitesi'nde beslenme ve barnma yardım alacak ögrencilerin belirlenmesi (Yüksek Lisans Tezi). Anadolu Üniversitesi Sosyal Bilimler Enstitüsü).

Guo, J. F., Li, H. P. ve Wei, X. L. (2013, June). The Evaluation of Scholarship for Undergraduate Based on AHP. In 2013 Conference on Education Technology and Management Science (ICETMS 2013). Atlantis Press.

Güngör, İ., Bakan, H., Aksu, M., Kiremitçi, S., Göksu, A. ve Göçen, S. (2010). Türkiye'de il olması uygun olan ilçelerin AHP yöntemi ile değerlendirilmesi. Alanya İsletme Fakültesi Dergisi, 2(2), 1-16. 
Hasan, P., Utami, E., Yunita, S. ve Pawan, E. (2019, July). Selection of scholarship acceptance using AHP and TOPSIS methods. In 2019 International Conference on Information and Communications Technology (ICOLACT) (pp. 920-925). IEEE.

Ho, W. (2008). Integrated analytic hierarchy process and its applications-A literature review, European Journal of Operational Research, 186, 211-228.

Indriantoro, S. C. ve Utami, A. W. (2016). Sistem pendukung keputusan pemberian beasiswa supersemar menggunakan metode promethee berbasis web. Jurnal Manajemen Informatika, 5(1).

Irvanizam, I. (2017, October). Multiple attribute decision making with simple additive weighting approach for selecting the scholarship recipients at Syiah Kuala university. In 2017 International Conference on Electrical Engineering and Informatics (ICELTICs) (pp. 245-250). IEEE.

İbicioğlu, H. ve Ünal, Ö. F. (2014). Analitik hiyerarşi proses ile yetkinlik bazlı insan kaynakları yöneticisi seçimi. Atatürk Üniversitesi İktisadi ve İdari Bilimler Dergisi, 28(4), 55-78.

Küçük, B., Demirci, E. ve Keskintürk, T. (2008). Bursiyerlerin genetik algoritma tekniği ile seçimi. Yöneylem Arasstırmasi ve Endüstri Mühendisliği 28. Ulusal Kongresi.

Mahmud, N., Pazil, N. S. M., Mazlan, U. H., Jamaluddin, S. H. ve Hasan, N. N. C. (2018). Scholarship eligibility and selection: A fuzzy analytic hierarchy process approach. In Proceedings of the Second International Conference on the Future of ASEAN (ICoFA) 2017-Volume 2 (pp. 175-183). Springer, Singapore.

Napitupulu, P. ve Surbakti, A. (2018, November). Design of decision support system providing scholarship with analytical hierarchy process (AHP) method on yayasan seri amal st. ignatius medan. In Journal of Physics: Conference Series, 1114(1), p. 012089. IOP Publishing.

Oğuzlar, A. (2007). Analitik hiyerarşi süreci ile müşteri şikayetlerinin analizi. Akdeniz I.İ.B.F. Dergisi, 7(14), 122-134.

Pençe, İ., Tarhan, L. ve Bozkurt, Ö. Ç. (2017). Türk Eğitim Vakfı Bursu verilecek uygun adayların AHP ve TOPSIS yöntemi kullanılarak belirlenmesi: Mehmet Akif Ersoy Üniversitesi Eğitim Fakültesi Örneği. Mehmet Akif Ersoy Üniversitesi Uygulamaln Bilimler Dergisi (MAKUUBD), 1(1), 37-49.

Purba, R. A. ve Sembiring, J. (2016, August). Selection of scholarship recipients by using PROMETHEE method in Polytechnic Unggul LP3M Medan. In 2016 International Seminar on Application for Technology of Information and Communication (ISemantic) (pp. 86-92). IEEE.

Puspitasari, T. D., Sari, E. O., Destarianto, P. ve Riskiawan, H. Y. (2018, January). Decision support system for determining scholarship selection using an analytical hierarchy process. In Journal of Physics: Conference Series, 953(1), 012119. IOP Publishing.

Putra, M. G. L., Ariyanti, W. ve Cholissodin, I. (2016). Selection and recommendation scholarships using AHPSVM-TOPSIS. Journal of Information Technology and Computer Science, 1(1), 1-13.

Saaty, T. L. (2008). Decision making with the analytic hierarchy process, International Journal of Services Sciences, 1(1), 8398.

Saaty, T. L. ve Niemira, M. P. (2006). A framework for making a better decision. Research Review, 13(1).

Saaty, T. L. (2016). The analytic hierarchy and analytic network processes for the measurement of intangible criteria and for decision-making. In Multiple criteria decision analysis (pp. 363-419). Springer, New York, NY.

Saptarini, N. G. A. P. H. ve Prihatini, P. M. (2015, October). Decision support system for scholarship in Bali state polytechnic using AHP and topsis. In Prosiding International conference on Information Technology and Business (ICITB) (pp. 38-46).

Saragih, H., Marbun, M. ve Reza, B. (2013). Development of decision support system determining the student as scholarship recipients by fuzzy multi attribute decision making (FMADM). Jurnal Sistem Informasi, 9(2), 75-81.

Satriani, N. N., Cholissodin, I. ve Fauzi, M. A. (2018). Sistem Pendukung Keputusan Penentuan Calon Penerima Beasiswa BBP-PPA Menggunakan Metode AHP-PROMETHEE I Studi Kasus: FILKOM Universitas Brawijaya. Jurnal Pengembangan Teknologi Informasi dan Ilmu Komputer e-ISSN, 2548, 964X.

Silva, V. B. D. S., Schramm, F. ve Carvalho, H. R. C. D. (2014). O uso do método PROMETHEE para seleção de candidatos à bolsa-formação do Pronatec. Production, 24(3), 548-558.

Sriwahyuni, T. S., Irfan, D., Dewi, I. P. ve Maharani, H. (2017). Development of Web-Based Decision Support Syatem for Scholarship Recipients Selection Using Analytical Hierarchy Process (AHP) Method. 4th International Conference on Technical and Vocation Education, Padang, November 9-11, 2017.

Sulaiman, N. H. ve Mohamad, D. (2006). A fuzzy logic model for students' scholarship selection. Jurnal Teknologi Maklumat dan Sains Kuantitatif, 8(1), 35-41.

Taufik, I., Syaripudin, U. ve Jumadi, J. (2017). Implementas1 Metode Promethee Untuk Menentukan Penerıma Beasiswa. Jurnal Istek, 10(1).

Uyun, S. ve Riadi, I. (2011). A fuzzy TOPSIS multiple-attribute decision making for scholarship selection. TELKOMNIKA, 9(1), 37-46.

Widiantoro, S. (2017, December). The Implementation of Analytical Hierarchy Process Method for Outstanding Achievement Scholarship Reception Selection at Universal University of Batam. In IOP Conference Series: Earth and Environmental Science, 97(1), 012003.

Yang, Y. W., ve He, Y. Y. (2019). Decision-Making Method Based on Picture Fuzzy Sets and Its Application in College Scholarship Evaluation. Decision-Making, 2(9), 48-57.

Yeh, C. H. (2003). The selection of multiattribute decision making methods for scholarship student selection. International Journal of Selection and Assessment, 11(4), 289-296. 


\section{EXTENDED ABSTRACT}

Non-refundable scholarships by both universities, local and national public and private institutions can be granted to students who are successful in higher education and whose financial status is insufficient. The number of applications for such scholarships can be very high, however, an objective assessment can be difficult in selecting a limited number of people. Multiple criteria decision-making methods can be used in order to rank and choose among many scholarship applications according to many criteria.

Multi-criteria decision-making methods are the methods used for the classification, ranking and selection of alternatives in cases where there are more than one criterion and more than one alternative. These methods have a very common use. Both individuals and institutions need to choose from alternatives in the short, medium and long term, there are usually more than one criterion to consider during this selection. Examples are the individual preference of any product (eg mobile phone, car, home) or institutional choice of any product or service (supplier selection, machine purchase, recruitment).

In this study, a solution has been brought to the problem of determining the students to be awarded a scholarship by using Analytical Hierarchy Process (AHP) and Preference Ranking Organisation Method for Enrichment Evaluations (PROMETHEE) methods.

Pairwise comparison mechanism of AHP is used for determining the weights of criteria. AHP uses a scale from 1 to 9 to compare the elements pairly. The comparison values constitue a matrix which shows the importance value of the element in the row against the element in the column. The pairwise comparison matrix is normalized by dividing the values to the sum of columns. Row averages of normalized matrix gives the priority values of compared elements. Five criteria and determined weights are income $(0,570)$, status of parents $(0,069)$, number of siblings $(0,182)$, family's home $(0,040)$ and social security $(0,139)$.

After determining the weights of five criteria the data is generated for a 50 -student example and PROMETHEE method is applied to rank students for scholarship. PROMETHEE has six preference functions for evaluating the alternatives according to a criterion. Through the preference functions the method allows decision maker to use different evaluations for different criteria. For each criterion a preference index matrix is calculated according to the preference function, preference index matrix shows the preference value of the element in the row over element in the column. The aggregated preference index matrix is calculated by weighted sum of preference index matrices. Positive outrankings $\left(\phi^{+}\right)$are calculated for each alternative by the sum of rows in the aggregated preference index. Negative outrankings $(\phi)$ are calculated for each alternative by the sum of columns in the aggregated preference index. PROMETHEE I makes a partial ranking by using positive and negative outrankings. PROMETHEE II makes a complete ranking by net outranking $(\phi)$ which is calculated by subtracting negative outranking from positive outranking. Net outranking values are the final priorities of the alternatives when sorted in descending order.

In this study Type-1 (usual) preference function for social security criterion, Type-4 (level) preference function for status of parents, number of siblings, family's home criteria and Type-5 (v-shape) preference function for income criterion were used according to requirements of the criteria. Final priorities of 50 students are calculated and first 10 are selected for the scholarship as an example.

AHP and PROMETHEE methods are proposed as a fair and easy to use model for student selection for scholarship problem. While determining the weights of criteria more pairwise comparison may be made to the decision maker, even to scholarship applicant students as a means of determining the weights fairly and with high representation. Furthermore, the interaction between criteria may be considered. For instance, status of parents may affect income or there may be a mutual effect between income and social security. In this condition Analytical Network Process (ANP) may be preferred for determining weights of criteria instead of AHP. 